\title{
Seboreik keratozun dermatoskopik görüntüleri ile histopatolojik alt tipleri arasında korelasyon
}

\section{Correlation between dermatoscopic findings and histopathological subtypes of seborrheic keratosis}

\author{
Rukiye Yasak*, Melih Akyol, Sedat Özçelik, Sibel Berksoy Hayta, Fahrettin Göze \\ Dermatoloji Kliniği (Dr. R. Yasak), Nazilli Devlet Hastanesi, TR-09800 Aydın, Dermatoloji \\ Anabilim Dalı (Prof. Dr. M. Akyol, Prof. Dr. S. Özçelik, Yrd. Doç. Dr. S. Berksoy Hayta), \\ Patoloji Anabilim Dalı (Prof. Dr. F. Göze) Cumhuriyet Üniversitesi Tıp Fakültesi, TR-58140 Sivas
}

\section{Özet}

Amaç. Seboreik keratoz daha çok yaşlılarda görülen benign karakterli epidermal bir tümördür. Akantotik, hiperkeratotik, irrite, retiküler, klonal tip ve melanoakantoma olmak üzere 6 farklı histopatolojik alt tipi vardır. Dermatoskopi (epiluminans mikroskopi) pigmente deri lezyonlarının çıplak göz ile görülemeyen klinik morfolojik özelliklerini gösteren in vivo, non-invaziv bir tekniktir. $\mathrm{Bu}$ çalışmadaki amacımız seboreik keratozun dermatoskopik özelliklerinin, histopatolojik alt grupları ile korelasyonu olup olmadığını saptamaktı. Yöntem. Çalışmaya alınan 53 hastanın toplam 80 adet SK lezyonu alındı. Dermatoskopik bulgular tanımlandı. 77 lezyondan insizyonel biyopsi alınırken üç lezyona total rezeksiyon yapıldı ve histopatolojik alt tipler velirlendi. Bulgular. SK alt tipleri; komedon benzeri açıklıklar, mila benzeri kistler, fissür, polimorf damar, ekzofitik papiller, dot/globül ve mavi beyaz yapı açısından değerlendirildiklerinde istatiksel olarak aralarındaki fark önemsiz bulunmuştur $(\mathrm{p}>0,05)$. Alt tiplerde sosis parmak hiperkeratotik tip ve irrite tip SK'da, milia-bulut irrite tip SK en fazla gözlenirken $(p<0,05)$, psödostreaks ve psödoretiküler patern en çok retiküler tip SK'da saptanmıştır $(p<0,05)$. Sonuç. Dermatoskopi, seboreik keratoz olgularında histopatolojik alt tiplerin belirlenebilmesine yardımcı bir tanı aracı olarak kullanılabilir.

Anahtar sözcükler: Seboreik keratoz, dermatoskopi, histopatolojik tip

\begin{abstract}
Aim. Seborrheic keratosis is a benign epidermal tumor, mostly seen in elderly. It has six histopatohological subtypes, including acantotic, hyperkeratotik, irritated, reticular, clonal type and melanoacantoma. Dermatoscopy (epiluminisence microscopy) is an in vivo, noninvasive technique showing invisible morhological properties of pigmented skin lesions and tumors. The aim of this study was to determine whether there is a correlation between dermatoscopic findings and histopathological subtypes of seborrheic keratosis. Method. 80 lesions from 53 patients were included the study. Dermatoscopic findings of the lesions were defined. Incisional biopsy of 77 lesions and excisional bopsy of three lesions were taken and histopathological subtypes were determined. Results. There was not a significant correlation between histopathological subtypes and some dermatoscopic findins, including comedo-like openings, milia-like cysts, fissures, polimorpheus vessels, dots/globules and blue-white structures $(\mathrm{p}>0.05)$. Sausage fingers were more frequent in hyperkeratotic irritated type of seborrheic keratosis $(\mathrm{p}<0.05)$. Milia-cloud was more frequent in irritated type, and pseudostreaks and pseudoreticular pattern was more frequent in reticular type of seborrheic keratosis $(\mathrm{p}<0.05)$. Conclusion. Dermatoscopy as a diagnostic tool may be used for the identification of some histopathological subtypes of seborrheic keratosis.
\end{abstract}

Keywords: Seborrheic keratosis, dermatoscopy, histopathologic type

Geliş tarihi/Received: 04 Haziran 2014; Kabul tarihi/Accepted: 12 Haziran 2014

\section{*İletişim adresi:}

Dr. Rukiye Yasak, Dermatoloji Kliniği, Nazilli Devlet Hastenesi, TR-09800 Aydın. E-posta: rky.yasak@net.com 


\section{Giriş}

Seboreik keratoz (SK), epidermal keratinosit proliferasyonu ile oluşan, yaşlılarda daha çok görülmesine karşın genç yaşlarda da ortaya çıkabilen, benign karakterli bir epidermal tümördür [1].

Vücudun hemen her bölgesinde oluşabilmekle beraber avuç içi, ayak tabanı ve mukozalarda görülmez $[1,2]$. Seboreik keratozlar tipik olarak düz, keskin sınırlı ve kahverengi maküller şeklinde başlarlar. Lezyon ilerledikçe polipoidal bir görünüm alırlar ve pürtüklü bir yüzey oluşur [1,3]. Folliküler tıkaçlar SK'un tipik özelliklerinden biridir. Koyu renkli lezyonda açık renkli tıkaçlar veya açık renkli lezyonda koyu renkli tıkaçlar şeklinde oluşabilirler. SK'lar tüm bu özellikler nedeni ile deriye 'yapışık' gibi görülürler $[1,3]$. Seboreik keratozun tüm tiplerinde epidermal değişiklikler ön planda olup, ortak histopatolojik bulgular hiperkeratoz, akantoz ve papillamatozdur. Hiperkeratotik, akantotik, irrite/inverte, klonal, retiküle ve melanoakantom olmak üzere 6 farklı histopatolojik tipi vardır [4].

Dermatoskopi (epiluminans mikroskopi, dermatoskopi, deri yüzey mikroskopi) pigmente deri lezyonlarının çıplak göz ile görülemeyen klinik morfolojik özelliklerini gösteren in vivo, non-invaziv bir tekniktir [5]. SK tanısı genellikle klinik olarak konur. SK'da en s1k görülen dermatoskopik özellikler komedon benzeri açıklıklar ve milia benzeri kistlerdir. SK'da s1k görülen diğer bir dermoskopik özellik irregüler, lineer şekilli ve keratin ile dolu fissürlerdir. Fissürler çok sayıda olduklarında lezyona 'beyin benzeri' bir görünüm verirler. Güve yeniği manzarası, parmak izi belirtisi, saç tokası damar yapısı, keskin kenar ve psödoağ yapıları da SK dermatoskopik bulguları arasında yer almaktadır [6-8]. Seboreik keratoz akantotik, hiperkeratotik, irrite ve inverted foliküler keratoz, retiküler, klonal, melanoakantoma adı altında altı tip histolojik alt gruba ayrılmaktadır [4].

$\mathrm{Bu}$ çalışmadaki amacımız, seboreik keratozun bu dermatoskopik özelliklerinin histopatolojik alt grupları ile korelasyon gösterip göstermediğini araştırmaktır.

\section{Gereç ve yöntem}

Çalışmaya 1.05.2010 ve 30.04.2011 tarihleri arasında Cumhuriyet Üniversitesi Tıp Fakültesi Dermatoloji Anabilim Dalı Polikliniği'ne başvuran 53 hasta alındı. Hastalarda SK tanısı klinik ve dermatoskopik olarak konuldu. Çalışmaya alınan 53 hastanın toplam 80 adet SK lezyonu dijital dermatoskopi (FotoFinder) ile hem makroskobik hem dermatoskopik kayıtları alınarak incelendi. İncelenen SK'lar Tablo 1'deki dermoskopik özellikler açısından ayrıntılı olarak iki farklı gözlemci tarafından aynı anda değerlendirildi.

Tablo 1. Seboreik keratoz lezyonlarında incelenen dermoskopik özellikler.

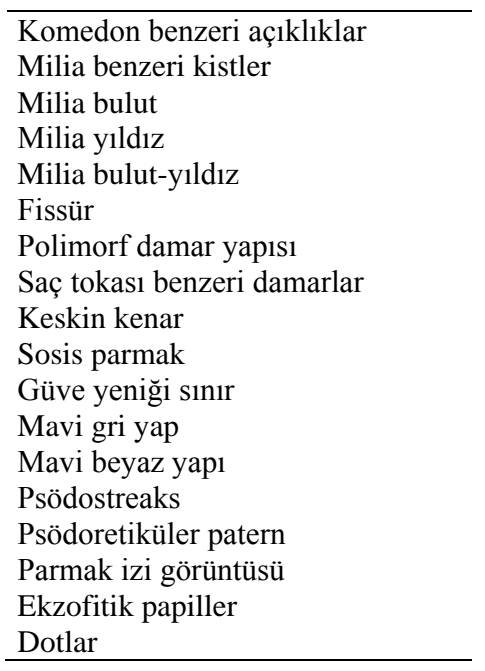




\section{İstatistiksel analiz}

İstatistiksel değerlendirmede SPSS (versiyon 14.0) programı kullanılarak Pearson testi ve Fisher exact test uygulandi.

\section{Bulgular}

Seboreik keratoz olguları akantotik, hiperkeratoz, irrite, retiküler, hiperkeratotik+akantotik ve diğer (klonal, melanoakantom, irrite+akantotik, retiküler+akantotik, hiperkeratotik+irrite) olmak üzere 6 grup altında toplandı.

Tablo 2'de alt tiplere göre bulunan olgu sayısı ve yüzdeleri verilmiştir. Üç adet inverted foliküler keratoz olgusu irrite tip içinde değerlendirilmiştir.

Tablo 2. SK alt tipleri ve yüzdeleri.

\begin{tabular}{lll}
\hline Seboreik keratoz alt tipleri & Sayı & Sıklık (\%) \\
\hline Akantotik & 23 & 28,8 \\
Hiperkeratotik & 29 & 36,2 \\
İrite & 7 & 8,8 \\
Retiküler & 7 & 8,8 \\
Klonal & 1 & 1,2 \\
Melanoakantom & 1 & 1,2 \\
Hiperkeratotik+akantotik & 7 & 8,8 \\
İrite+akantotik & 2 & 2,5 \\
Hiperkerattotik+irrite & 1 & 1,2 \\
Hiperkeratotik+retiküle & 2 & 2,5 \\
\hline Toplam & $\mathbf{8 0}$ & $\mathbf{1 0 0}$ \\
\hline
\end{tabular}

SK olgularının, 23 (\%28,75)'ünü akantotik, 29 (\%36,25)'unu hiperkeratotik, 7 $(\% 8,75)$ 'sini irrite, $7(\% 8,75)$ 'sini retiküle, $1 \quad(\% 1,25)$ 'ini klonal, $1 \quad(\% 1,25)$ 'ini melanoakantom, $7(\% 8,75)$ 'sini hiperkeratotoik ve akantotik, $2(\% 2,5)$ 'sini irrite ve akantotik, $2(\% 2,5)$ 'sini hiperkeratotik ve retiküle tip seboreik keratoz oluşturken son 1 $(\% 1,25)$ tanesini de hiperkeratotik ve irrite tip seboreik keratoz oluşturmakta idi (Resim $1)$.
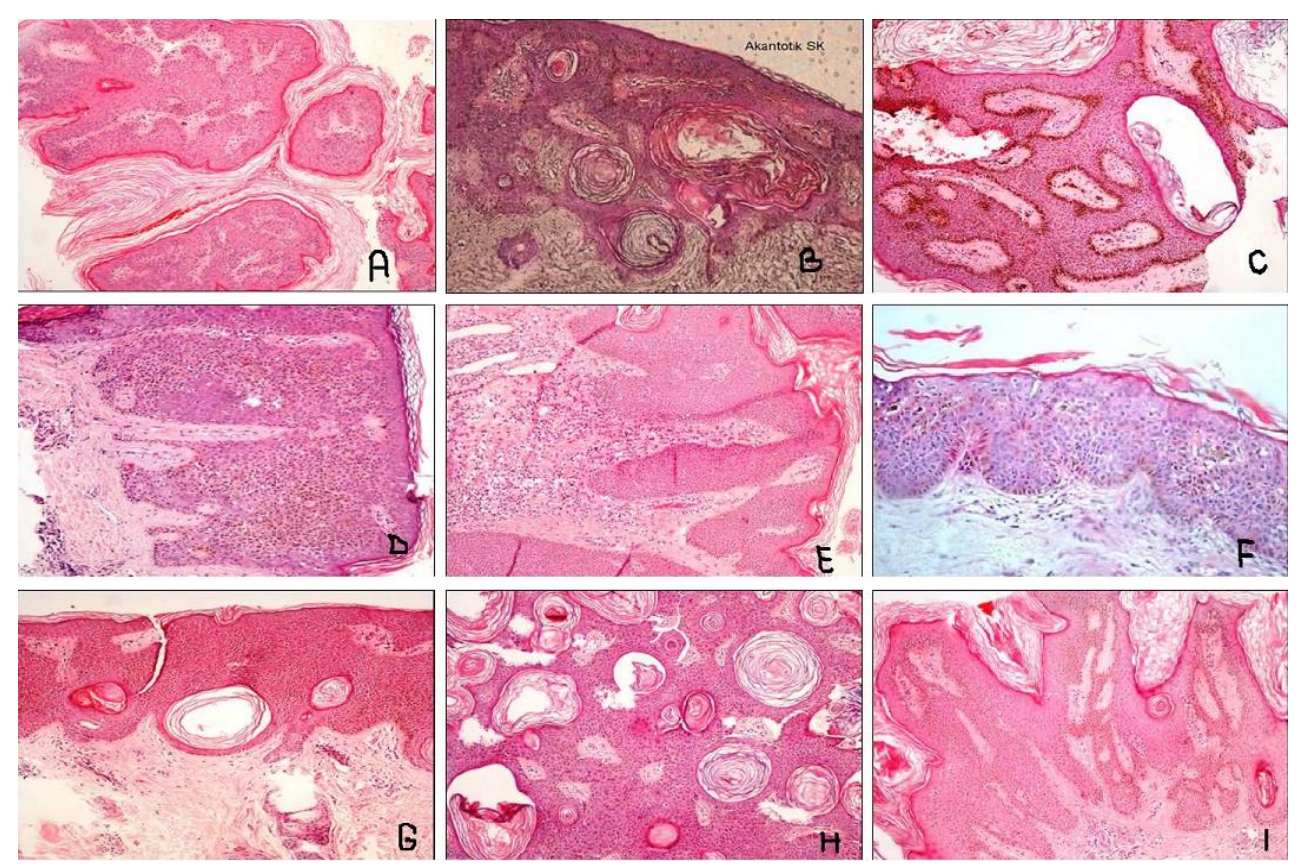

Resim 1. A; hiperkeratotik tip, B; akantotik tip, C; retiküle tip, D; klonal tip, E; inverted folliküler keratoz, F; melanoakantom, G; irritatif tip, H; akantotik+irrite Tip I; retiküle+hiperkeratotik tip. 
Olgular alt tiplerine göre genel komedon açısından değerlendirildiğinde farklılık önemsiz bulunmuştur $\left(X^{2}=9,95 ; p<0,05\right)$. İstatiksel olarak önemsiz olmasına rağmen 7 adet irrite tipin 6'sında $(\% 85,7)$ komedon saptanmıştır. SK alt tipleri ayrı ayrı karşılaştırıldığında ise hiperkeratotik ve akantotik tip arasında istatiksel olarak anlamlı ilişki saptanmıştır $\left(\mathrm{X}^{2}=4,41 ; \mathrm{p}<0,05\right)$. Akantotik tipte daha fazla komedon görülmektedir (Resim 2).

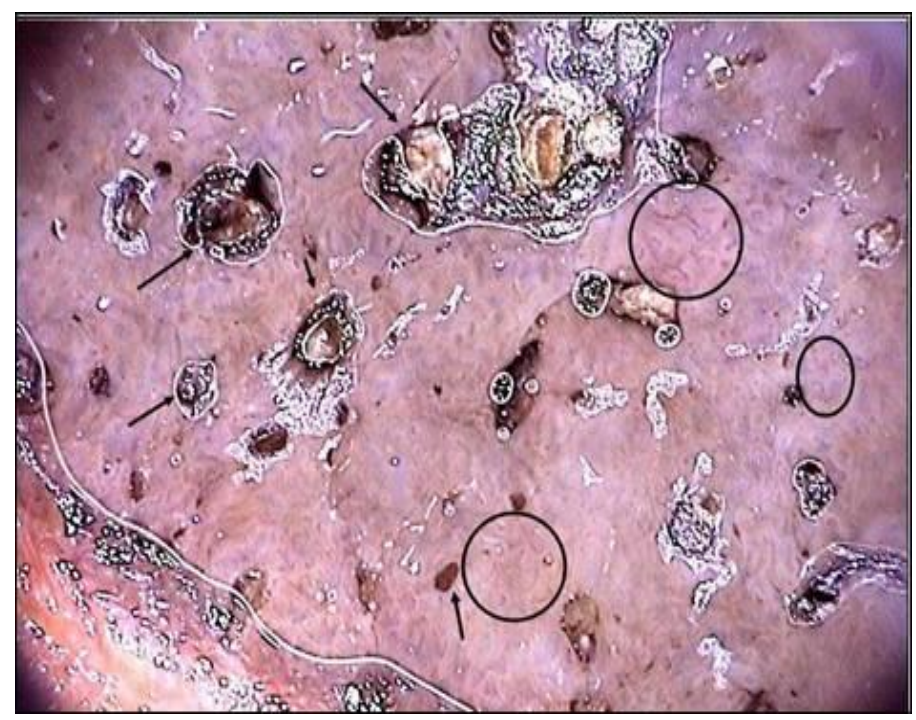

Resim 2. Akantotik tip SK dermoskopi (komedon $\rightarrow$ saç tokası damar, çember).

Olgular alt tiplerine göre genel milia açısından değerlendirildiğinde farklılık önemsiz bulunmuştur $\left(X^{2}=10,671 ; p=0,05\right)$. SK alt tipleri ayrı ayrı karşılaştırıldığında ise hiperkeratotik ve akantotik tip arasında istatiksel olarak anlamlı ilişki saptanmıştır $\left(\mathrm{X}^{2}\right.$ $=5,63 ; p<0,05)$. Genel komedona benzer şekilde akantotik tipte daha fazla milia benzeri kistler görülmektedir.

Milia benzeri kistler milia bulut, milia yıldız, milia bulut-yıldız olarak değerlendiriliğinde ise milia bulut SK alt tiplerinde istatiksel olarak anlamlı bulundu. İrite tip SK'da daha fazla oranda milia bulut görülmüştür $\left(X^{2}=11,09 ; \mathrm{p}<0,05\right)(\operatorname{Resim} 3)$.

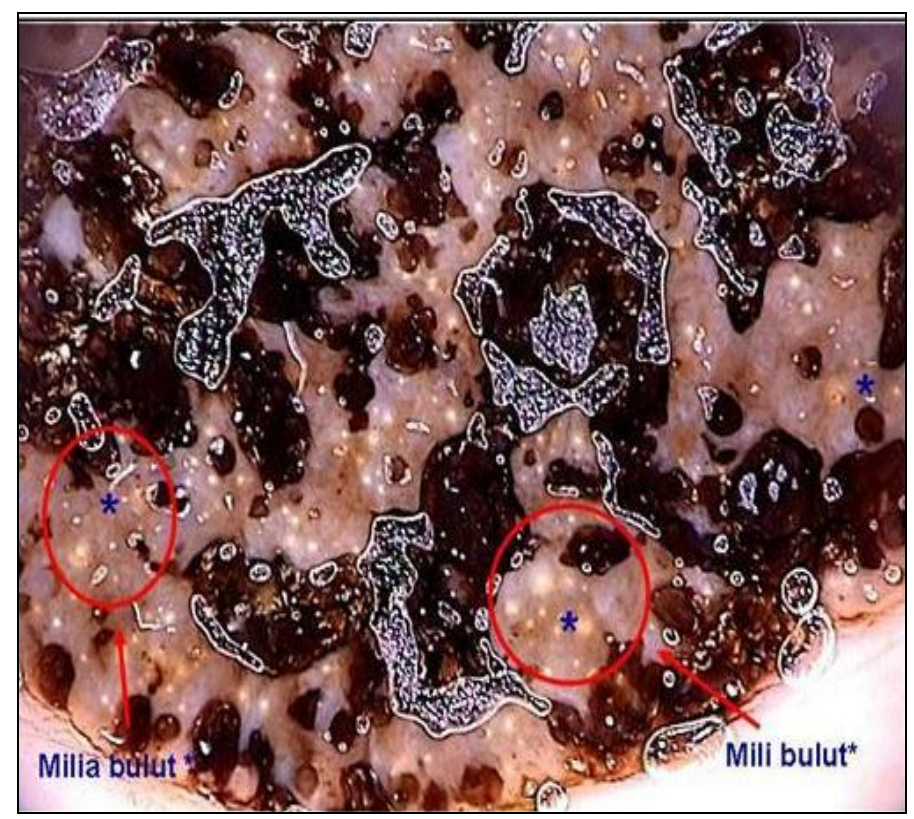

Resim 3. İrrite tip SK'da milia-bulut*. 
SK alt tiplerinden akantotik ve hiperkeratotik tip kendi aralarında milia-bulut açısından değerlendirildiğine istatiksel olarak anlamlı bulunmuştur. Akantotik tip SK'da hiperkeratotik tip SK'a oranla daha fazla milia bulut saptanmıştır. $\left(X^{2}=4,39, p<0,05\right)$. Aynı şekilde irrite tip ve hiperkeratotik tip kendi arasında değerlendirildiğinde irrite tip SK' da daha fazla oranda milia-bulut bulunmaktadır $(\mathrm{p}<0,05)($ Resim 4$)$.

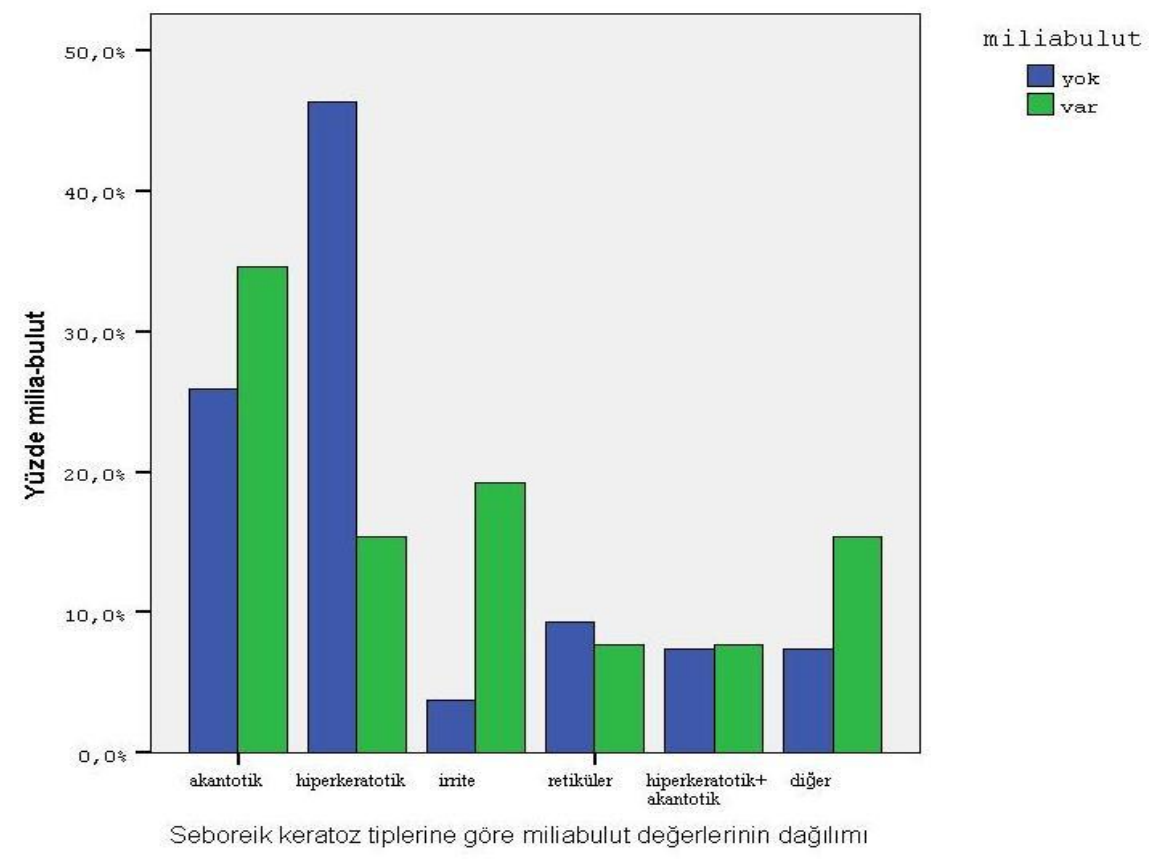

Resim 4. Seboreik kertaoz tiplerine göre milia-bulut dağılımı.

Ayrıca olgular alt tiplerine göre fissür açısından değerlendirildiğinde farklılık önemsiz bulunmuştur $\left(X^{2}=10,882 ; p>0,05\right)$. SK alt tipleri ayrı ayrı karşılaştırıldığında ise hiperkeratotik ve akantotik tip arasında istatiksel olarak anlamlı ilişki saptanmıştır $\left(\mathrm{X}^{2}=4,39 ; \mathrm{p}<0,05\right)$. Hiperkeratotik tipte daha fazla fissür görülmektedir. İstatiksel olarak anlamsız olmakla birlikte retiküle tip SK' da fissür gözlenmemiştir.

SK alt tipleri sosis parmak açısından değerlendirildiğinde alt tipler arasındaki fark istatiksel olarak anlamlı bulundu $\left(X^{2}=11,24 ; p<0,05\right)$. Hiperkeratotik tip SK $(\% 55,1)$ ve irrite tipte $(\% 57,2)$ daha fazla oranda sosis parmak görünümüne rastlanmaktadır (Resim $4)$. 


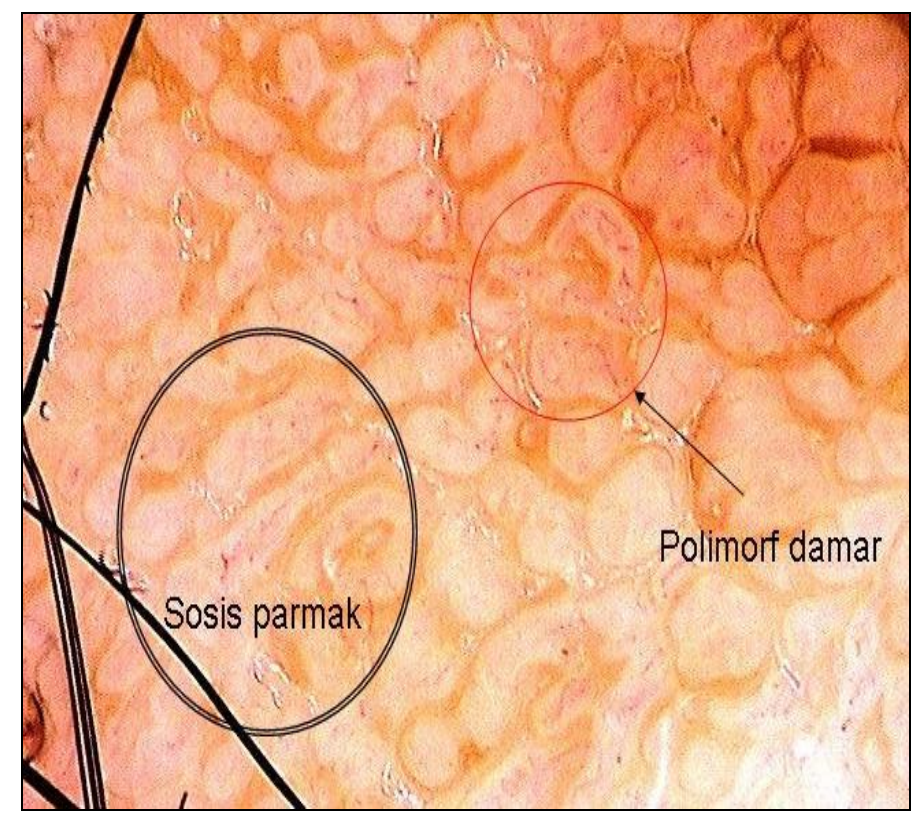

\section{Resim 5. Hiperkeratotik tip SK'da sosis parmak.}

Çalışmaya alınan SK alt tipleri polimorf damar açısından değerlendirildiğinde istatiksel olarak farklılık a Psödostreaks açısından değerlendirildiğinde ise istatiksel olarak SK alt tiplerinde anlamlı farklılık bulunmuştur. Retiküler tip SK'da daha fazla oranda pödostreaks saptanmıştır $\left(X^{2}=11,6 ; \mathrm{p}<0,05\right)$. Psödoretiküler patern açısından da alt gruplar değerlendirildiğinde, retiküler tip SK da istatiksel olarak fark önemli bulunmuş̧tur. Yine retiküler tip SK'da psödoretiküler patern daha sik gözlenmektedir $\left(X^{2}=28,29 ; p<0,05\right)($ Resim 6).
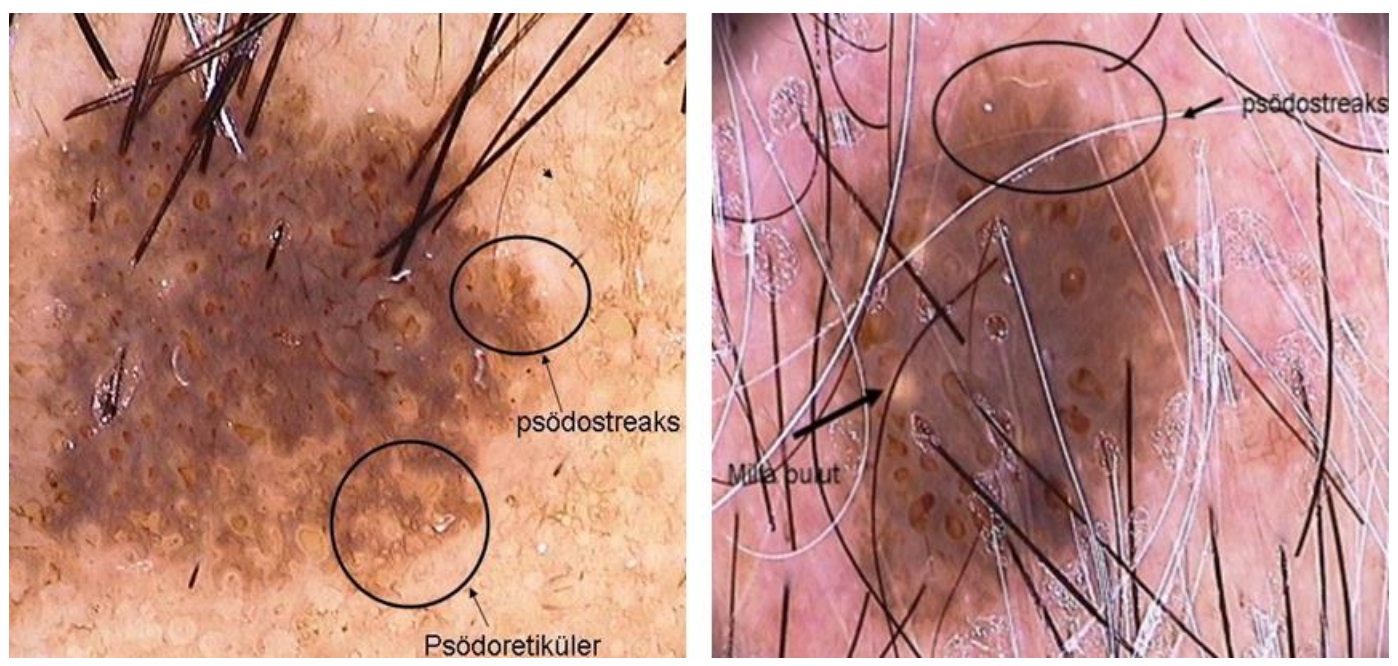

Resim 6. Retiküler tip SK psödoretiküler ve psödostreaks.

SK alt tiplerine göre ekzofitik papiller durumu açısından incelendiğinde istatiksel faklılıklar önemsiz bulunmuştur $\left(X^{2}=4,067 ; p>0,05\right)$.

Mavi-gri yap1 SK alt tiplerine göre incelendiğinde istatiksel olarak farklılık önemsiz bulunmuştur $\left(X^{2}=8,641 ; p>0,05\right)$. İstatiksel olarak anlamsız olmasına rağmen SK alt tiplerinin hiçbirinde parmak izi saptanmamıştır. Dot varlığı açısından değerlendirildiğinde ise alt tipler arasında farklılık istatiksel olarak anlamsız bulunmuştur $\left(X^{2}=3,55 ; p>0,05\right)$. Ayrıca mavi-beyaz yapı varlığı araştırıldığında yine alt tipler arasındaki farklılık istatiksel olarak anlamsız bulunmuştur $\left(X^{2}=3,41 ; p>0,05\right)$. 
80 adet SK olgusundan sadece bir adet klonal tip SK ve bir adet melanoakantom saptanmıştır. Klonal tip SK dermatoskopisinde çok sayıda komedon, ekzofitik papiller, saç tokası damarlar, mavi-gri yapı hipopigmente alan ile keskin kenar saptanmıştır. Melanoakantomun dermatoskopik görüntüsünde ise komedon, milia bulut-yıldız, saç tokası damar, dot, keskin kenar ve beyaz yapı gözlenmiştir (Resim 7, 8).

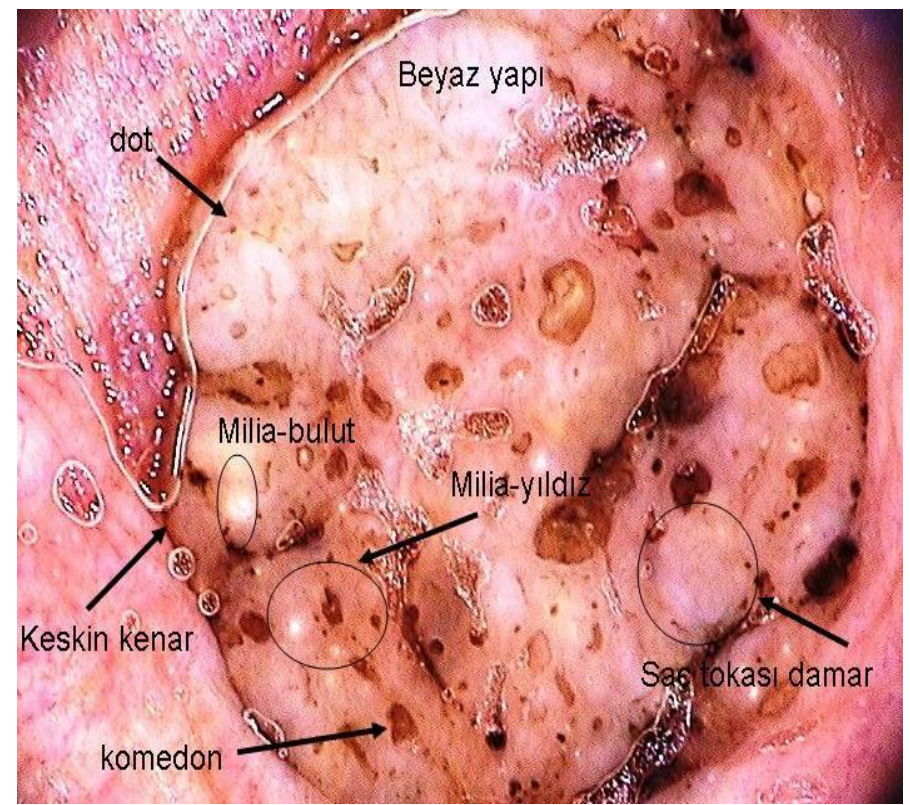

Resim 7. Melanoakantom tip SK'da dermatoskopik görüntü. Melanoakantomun dermatoskopik görüntüsünde ise komedon, milia bulut-yıldız, saç tokası damar, dot, keskin kenar ve beyaz yapı gözlenmiştir. $[(\rightarrow)$ Komedon, $(\times)$ hipopigmente alan].
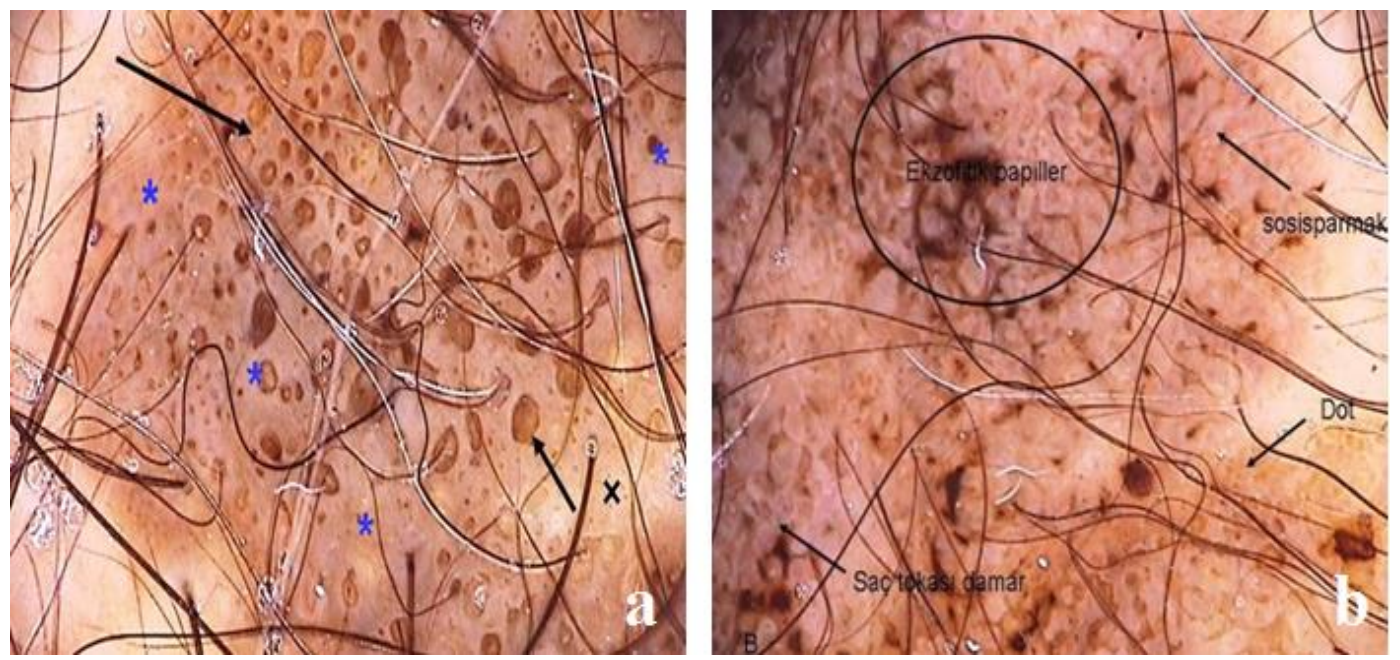

Resim 8. Klonal tip SK'da dermatoskopik görüntü. SK dermatoskopisinde çok sayıda komedon, ekzofitik papiller, saç tokası damarlar, mavi-gri yapı hipopigmente alan ile keskin kenar saptanmıştır. a; klonal tip SK $\left(^{*}\right)$ mavi-gri yapı, b; Klonal tip SK. $[(\rightarrow)$ Komedon, $(\times)$ hipopigmente alan]. 


\section{Tartışma}

Seboreik keratoz (SK) epidermal keratinositlerden kaynaklanan ve ileri yaşlarda daha sık görülen, genellikle pigmente benign bir tümördür [9].

Seboreik keratozlarda prevalans, cinsiyet, ırk veya coğrafik dağılımla ilgili çok az epidemiyolojik istatistiksel çalışma vardır. SK'ların 30 yaşın altında görülmeleri beklenmez. SK'ların başlangıç yaşı genellikle 3 ile 5. dekatlardır [2]. Bizim çalışmamızda SK görülme sıklığ $14-29$ yaş grubunda $\% 5,7 ; 30-35$ yaş grubunda $\% 9,4 ; 46-59$ yaş grubunda $\% 26,4 ; 60-75$ yaş grubunda $\% 37,7$ ve 76 yaş üstünde ise $\% 20,8$ oranında görülmüştür.

Dermoskopi (epiluminans mikroskopi, dermatoskopi, deri yüzey mikroskopi), pigmente deri lezyonlarının tanısında çıplak gözle görülemeyen morfolojik özelliklerin görülebilmesini sağlayan, basit, non-invaziv bir tanı yöntemidir [5]. Pigmente deri lezyonlarının pigmentasyon özellikleri, homojeniteleri, şekilleri, sınır ve yüzey özellikleri dermatoskopi ile değerlendirilir. SK tanısı genellikle klinik olarak konulmakla beraber bazı hastalarda pigmente SK ile malign melanom ayırıcı tanısı güç olabilir. Bu nedenle dermatoskopik inceleme SK tanısı ve ayırıcı tanısında büyük avantajlar sağlar [6, 10].

SK'da en s1k görülen dermatoskopik özellikler komedon benzeri açıklıklar ve milia benzeri kistlerdir. Ayrıca liner şekilli ve keratin ile dolu fissürler de çok sık gözlenir. Fissürler çok sayıda olduklarında lezyona 'beyin benzeri' bir görünüm verirler. 'Sosis parmaklar' SK'daki tipik dermatoskopik yapilar arasındadır [10]. Komedon benzeri açıklıklar ve milia benzeri kistler gibi bazı dermatoskopik bulguların histopatolojik tanıyla yüksek derecede uyum gösterdiği de bilinmektedir [11].

Braun ve ark. [10]'nın yapmış olduğu bir çalışmada 203 pigmente SK'un 144 lezyonunda; komedon benzeri açıklıklar (\%71), 135 lezyonunda; miliabenzeri kistler (\%66), 129 lezyonunda; saç tokası kan damarları (\%63) ve 183 lezyonda ise keskin kenar (\%90) saptamışlardır. Ayrıca 124 lezyonda fissürler (\%61), 94 lezyonda güve yeniği sınırı (\%46) ve 94 lezyonda pigment ağı (\%46) saptamışlar. Soyer ve ark. [12] pigmente lezyonları dermatoskopik ve histopatolojik olarak kıyasladıkları bir çalışmada üç majör SK alt tiplerinden akantotik, hiperkeratotik ve retiküle tipin dermatoskopik görünümlerini araştırmışlardır. Akantotik tip SK'da az sayıda milia-benzeri kist ile az sayıda komedon benzeri açıklıklar tespit etmişlerdir. Hiperkeratotik tip SK'da ise yoğun ortakeratozdan dolayı spesifik bir dermatoskopik görüntü bulamamışlardır.

Bizim çalışmamızda ise SK alt tiplerine bakmaksızın \%67,9 komedon benzeri açıklıklar, $\% 53,8$ polimorf damar, $\% 47,5$ saç tokası şeklinde damar yapısı, $\% 40$ milia benzeri kist, $\% 37,5$ sosis parmak, \%27,5 fissür, \%6,2 ekzofitik papiller gözlenmiştir. İstatiksel olarak önemsiz olmasına rağmen 7 adet irrite tipin 6' sında $(\% 85,7)$ komedon saptanmıştır. SK alt tipleri ayrı ayrı karşılaştırıldığında ise hiperkeratotik ve akantotik tip arasında istatiksel olarak anlamlı ilişki saptanmıştır. Soyer ve ark. [12]'nın çalışmasına benzer şekilde akantotik tipte daha fazla komedon görülmektedir. Çalışmamızda istatiksel olarak anlamlı olmamakla birlikte milia benzeri kistler; irrite ve retiküle tipte $\% 57,1$ oranında gözlenirken, hiperkeratotik ve akantotik tip karşılaştıııldığında ise yine Soyer ve ark. [12]'nın çalışmasına benzer şekilde akantotik tipte daha fazla milia benzeri kist görülmektedir.

Pigmente SK'da lezyonun periferinde 'saç tokası kan damarları' şeklinde spesifik vasküler yapı bulunabilir. Özellikle irrite tip SK tipik saç tokası damarlar gözlenmektedir [6]. Karaarslan ve ark. [13]'nın yapmış oldukları bir çalışmada \%1,4 oranında saç tokası şeklinde damar yapısı ile \%4 oranında polimorf atipik damar yapısı tespit etmişlerdir. Bizim çalı̧̧mamızda ise SK olgularının \%53,8'sinde polimorf damar, $\% 47,5$ 'sinde ise saç tokası kan damarları gözlenmiştir. SK alt tiplerine göre değerlendirdiğimizde ise saç tokası kan damarları \%60,9 oranında akantotik tipte gözlenirken, polimorf damar yapısı ise \% 71,4 oranında irrite tip SK' da gözlenmiştir. 
SK'daki bir diğer tipik dermatoskopik yapı ise sosis parmaktır. Kahverengi, mavi, hipopigmente (amelanotik) renklerde olabilirler. Lineer (uzun parmak), semilineer (kıvrılmış parmak), dallanmış ve oval-sirküler şekilde olabilirler. Bizim çalışmamızda ise genel olarak 80 olgunun $\% 37,5$ 'inde sosis parmak, \%27,5'inde fissür ve \%6,2 ekzofitik papiller yapı bulunmuş olup benzer çalışmalarla benzerlik göstermektedir. SK alt tiplerine göre değerlendirildiğinde ise sosis parmak en çok irrite tipte $(\% 57,1)$ ve hiperkeratotik tipte $(\% 55,2)$ tespit edilmiştir. Ayrıca hiperkeratotik tip ve hiperkeratotik+akantotik tip kendi aralarında değerlendirildiğinde ise hiperkeratotik tipte daha fazla oranda sosis parmak gözlenmiştir. Aynı şekilde fissür için akantotik ve hiperkeratotik tipi değerlendirdiğimizde ise hiperkeratotik tipte daha fazla fissür saptanmıştır. Ayrıca çalışmamızda Soyer ve ark. [12]'nın çalışmasına benzer şekilde akantotik tip SK'da daha çok ekzofitik papiller yapı gözlenmiş̧ir.

Braun ve ark. [10] ise yapmış oldukları 203 SK içeren diğer bir çalışmada $\% 46$ oranında ağ benzeri yapı bulduklarını bildirmişlerdir. Bizim çalışmamızda 80 SK olgusunun $\% 16,2$ 'sinde psödostreaks ve aynı şekilde \%16,2'sinde de psödoretiküler patern izlenmiştir. Olgular SK alt tiplerine göre değerlendirildiğinde ise en çok psödostreaks $\% 57,1$ oranında retiküler tip SK'da gözlenirken yine $\% 85,7$ oranla psödoretiküler patern retiküler tip SK gözlenmiştir. İrrite tip SK oldularında ise psödoretiküler yapı ve psödostreaks gözlenmemiştir.

Mavi-beyaz veya mavi-gri yapı herhengi bir tipteki mavi ve/veya gri-beyaz renk olarak tanımlanır. Mavi-beyazımsı peçe ve regresyon yapılarını temsil eder. Karaarslan ve ark. [13]'nın çalışmasında 214 SK olgusunda sadece iki tanesinde mavi-beyazımsı peçe yapısı saptamışlardır ve bunu hiperkeratozik epidermis altındaki dermiste, melanin pigment birikimine bağlamışlardır. Bizim çalışmamızda ise $\% 35$ oranında mavi-gri yapı ve $\% 13,8$ oranında mavi-beyaz yapı saptanmıştır. Peçe görünümü olan iki olguya BCC, seboreik keratoz ön tanıları ile total eksizyon yapılmış olup, olgulardan biri inverted foliküler keratoz, diğeri ise inflame tip SK olarak rapor edilmiştir. Bu görünüm her ikisinin de etyolojisinde yer alan travmaya sekonder gelişmiş olabilir.

Histopatolojik olarak SK alt tiplerinden en çok akantotik tip SK'un görülmektedir [4]. Bizim çalışmamızda ise alt tiplerden en çok hiperkeratotik tip SK $(\% 36,6)$ bulunmuştur. Histopatolojik ve dermatoskopik olarak incelenen 80 lezyonun tamamının (\%100) histopatoloji sonucu SK olarak yorumlanmıştır.

Provost ve ark. [14]'nın SK'da kahverengi globül benzeri yapılar tanımlamışlardır. Karaarslan ve ark. [13]'nın yapmış oldukları çalışmada \%9,4 oranında globüle rastlanmıştır. Hirata ve ark. [15]'nın 250 SK içeren çalışmasında $4(\% 1,69)$ olguda globül tespit edilmiş ve bu 4 SK klonal tip SK olarak bildirilmiştir. Bizim çalışmamızda 80 SK olgusunda dot ve globül bir arada değerlendirilmiş ve \%60 oranında dot ve globül tespit edilmiştir.

Dermatoskopik özelliklerin bilinmesi yalnızca histopatolojik tiplerin belirlenmesi açısından değil aynı zamanda yeni yapılan bir çalışmada olduğu gibi apoptozisle ilgili değerlendirme yapabilmek için de önemlidir [16].

Dermatoskopi, histopatolojik değerlendirme öncesi tümöral bir lezyonun malign-benign ayırımının yanısıra seboreik keratoz olgularında histopatolojik alt tiplerin belirlenebilmesine de yardımcı bir tanı aracı olarak kabul edilebilir. 


\section{Kaynaklar}

1. Burns T, Breathnach S, Cox N, Griffiths C. Benign epidermal tumors. In: Rook's Textbook of Dermatology 8th ed. London, Blacwell 2010; 52: 38-9.

2. James W, Berger T, Elston D Epidermal nevüsler, neoplaziler, kistler. In: Andrew's Klinik Dermatoloji 10.bask1. İstanbul 2008, 637-9.

3. Silver SG, Ho VCY. Benign epithelial tumors. In: Freedberg IM, Eisen AZ, WollfK, AustenKF, GoldsmithLA, Katz SI, editors. Fitzpatrick'sDermatology in General Medicine, 6th edition, Newyork: McGraw Hill 2003; 767-70.

4. Kirkham N. Tumors and cysts of the epidermis. In: Elder D, Elenitsas R, Jaworsky C, Johnson B, editors. Leveres Histopatology of the skin. 8th ed. Philadellphiz: Lippincott-Raven Publishers 1997: 685-746.

5. Rossiello L, MD, Zalauder I, Ferrare G. Melanoacanthoma simulating pigmented spitz nevus: An usual dermoscopy pitfall. Dermatol Surg 2006; 32: 735-7.

6. Braun R, Rabinovitz H, Oliviero M. Dermoscopic diagnosis of seborrheic keratosis. Clin Dermatol 2002; 20: 270-2.

7. Kopf AW, Rabinovitz H, Marghoob A, Braun RP, Wang S, Oliviero M, Polsky D. "Fat fingers": A clue in the dermoscopic diagnosis in seborrheic keratoses $\mathrm{J}$ Am Acad Dermatol 2006; 55: 1089-91.

8. Takenouch T. Key points in dermoscopic diagnosis of basal cell carcinoma and seborrheic keratosis in Japanese. J Dermatol 2011; 38: 59-65.

9. Burgdorf WHC, Plewig G. Wolff HH. Landthaler M. Benign epithelial tumors. Braun-Falco's Dermatology third edition, Berlin 2009; 1340-2.

10. Braun RP, Rabinovitz HS, Oliviero M, Kopf AW, Saurat JH. Dermoscopy of pigmente skin lesions. J Am Acad Dermatol 2005; 52: 109-21.

11. Lin J, Han S, Cui L, Song Z, Gao M, Yang G, Fu Y, Liu X. Evaluation of dermoscopic algorithm for seborrhoeic keratosis: A prospective study in 412 patients. J Eur Acad Dermatol Venereol. 2013.

12. Soyer H, Argenziano G, Ruocco V, Dermoscopy of pigmented skin lesions (part II). Eur J Dermatol 2001; 11: 483-98.

13. Karaarslan I, Bıyıklı E, Akalın T, Özdemir F. Seboreik keratozların dermoskopik özellikleri; yalancı melanositik lezyon kriterlerinin yeri nedir? Türk Dermatoloji Dergisi 2009; 3: 1-4.

14. Scope A, Benvenuto-Andrade C, Agero ALC, Marghoob AA. Nonmelonocytic lesions defying the two-step dermoscopy algorithm. Dermatol Surg 2006; 32: 1398-406.

15. Scope A, Agero CA. Nonmelonocytic lesions defying the two-step dermoscopy algorithm. Dermatol Surg 2006; 32: 1398-406.

16. Simionescu O, Popescu BO, Costache M, Manole E, Spulber S, Gherghiceanu M, Blum A. Apoptosis in seborrheic keratoses: An open door to a new dermoscopic score. J Cell Mol Med 2012; 16: 1223-31. 